\title{
Agricultural potential of areas under pasture in southern Tocantins
}

\section{Aptidão agrícola de áreas sob pastagem no sul do Tocantins}

\author{
Jefferson Santana da Silva Carneiro ${ }^{1, *}$ (D) , Dayane Barros da Silva 2, (iD , Robson da Costa Leite 2,(iD)

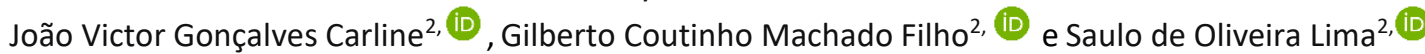 \\ 1 Universidade Federal de Lavras (UFLA). CEP 37200000. Lavras-MG, Brasil. \\ 2 Universidade Federal do Tocantins, Campus Universitário de Gurupi. Rua Badejos Lt. 07 Ch. 69/72 Zona rural Zona Rural. \\ Caixa-postal: 66, CEP 77402-970. Gurupi-TO, Brasil. \\ *Autor para correspondência: carneirojss@yahoo.com.br
}

OPPEN ACESS

\section{Additional information}

Received: $10 / 12 / 2016$

Accept: 02/19/2017

Published: 04/16/2017

Editor:

Vinicius Batista Campos Federal Institute of Amapá, Macapá, AP.

vinicius.campos@ifap.edu.br

\section{Double blind reviews}

Reviews process

Prot. $1232016 R 01$ (Brazil)

Prot. $1232016 R 02$ (Brazil)

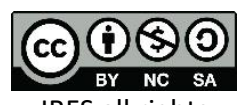

JBFS all rights

Copyright: (C) 2017

\section{ABSTRACT}

Improper soil use leads to inefficient exploitation of natural resources, destruction of land resources, poverty and other social problems. Therefore, the objective of this study was execute a survey and soil classification of an area under pasture in a farm in southern Tocantins. The area was divided according to the existing soil spots to perform the soil classification following the methodology of the Brazilian System of Soil Classification and its agricultural potential. At the studied area were found four soil classes, which were studied and classified as Plintossolo Argilúvico Distrófico petroplíntico, Cambissolo Háplico Tb Eutrófico, Latossolo Vermelho-Amarelo Distrófico típico and Gleissolo Melânico Ta Eutrófico with agricultural potential in the subgroups $1(\mathrm{a}) \mathrm{bC}, 4 \mathrm{P}, 1 \mathrm{aBC}$ and $3(\mathrm{bc})$, respectively. The terrain was underutilized, being used for pasture cultivation, at the same time it could be used for cultivation of annual plants.

Keywords: Soil. Aptitude. Fertility.

\section{RESUMO}

O uso inadequado da terra leva à exploração ineficiente dos recursos naturais, à destruição dos recursos da terra, à pobreza e outros problemas sociais. Diante disso, o presente trabalho teve como objetivo realizar o levantamento de solo em uma área sob pastagem localizada no sul do estado de Tocantins. A área foi dividida segundo as manchas de solo existentes para realizar a classificação dos mesmos segundo a metodologia do Sistema Brasileiro de Classificação de Solos e sua aptidão agrícola. A área de estudo apresentou quatro classes de solos, as quais foram estudadas e classificadas como Plintossolo Argilúvico Distrófico petroplíntico, Cambissolo Háplico Tb Eutrófico, Latossolo Vermelho-Amarelo Distrófico típico e Gleissolo Melânico Ta Eutrófico com aptidão agrícola nos subgrupos $1(\mathrm{a}) \mathrm{bC} ; 4 \mathrm{P} ; 1 \mathrm{aBC}$ e $3(\mathrm{bc})$, respectivamente. 0 terreno estudado apresentou-se subutilizado, com cultivo de pastagem, enquanto poderia ser empregado para o cultivo de plantas anuais.

Palavras-chave: Solo. Aptidão. Fertilidade. 


\section{INTRODUCTION}

In general, inappropriate use of soils leads to an inefficient exploitation of natural resources, consequently causing environmental, economic and social impacts. Meanwhile, degradation process controls in rural areas are complex and should adopt agricultural policies that contemplate the maintenance and/or increase of soil productive (ROSSITER, 1996; BARBOSA NETO, 2011). Thus, the study of soil resources are extremely important, being the chemical, physical and morphological characterization important subsidies for understanding and application of technologies in agriculture (GUIMARÃES et al., 2013). Soil classification gives an idea of the depth of attributes and diagnostic horizons, wherefore guiding information about restriction and agricultural practices or engineering actions that should be used (OLIVEIRA, 2008).

According to Schneider et al. (2007) and Barbosa Neto (2011), a basic step in the conservation planning of rural properties or larger areas, such as watershed, cities or regions, is the classification of land agricultural potential. This classification is based on interpretation of land characteristics from different areas or soil orders in capability classes for agriculture. The interpretation of soil surveys has highest relevance for rational use of natural resource in agriculture (Moura et al., 2007). In other words, it is a process used as a guidance for planning of natural resource use, identifying how and how much land can be used in the agroecosystems (Barbosa Neto, 2011). Moreover, second Barbosa Neto (2011) different edaphoclimatic attributes may have distinct weights in evaluations, in function of relative importance to a particular environment and relevance for farming systems.

One of the most important activity with conservation purposes is the soil use survey, obtained crossing agricultural capability with current land use information. Therefore, it can perform a verification of conflicts between actual use and soil potential. Moreover can indicate conservation management techniques for the studied area (BARBOSA NETO, 2011).

Currently, soil conservation is definitely one of the most important aspects of modern agriculture. Thus, there is the necessity of a technical orientation order that agricultural holdings can be conducted in conservation bases, without ignoring at the same time the financial interests of the farmers. For this, rational planning land use is necessary, in view of all its main soil, ecological and economic characteristics and agricultural potential (Barbosa Neto, 2011). In this sense, the objective of this study is to characterize and evaluate agricultural potential of soils under pasture in southern Tocantins.

\section{MATERIAL AND METHODS}

The study was carried out at Nelore Brilhant farm, with geographic coordinates $11^{\circ} 37^{\prime} 29.53^{\prime \prime}$ S and $49^{\circ} 02^{\prime} 45.20^{\prime \prime} \mathrm{W}$ and 296 meters above sea level. The area is located in the southern region of the State of Tocantins. According to the Köppen climate classification system the area where soil was collected is B1WA'a', or wet with moderate water deficit (KÖPPEN, 1948).

First, was performed mapping by delimiting study area and soil stains. Mapping was performed by using a GPS (GARMIN ETREX 20) crossing entire area, taking coordinates and marking observed soil stains. For soil classification, was made physical, chemical and morphological soil study profile under "Manual de descrição e coleta de solo no campo" (SANTOS et al., 2013).

Four soil pits were dug for description and sampling of the profiles. With dug pits and exposed soil, horizons were identified by delimiting them with a millimeter tape 
measure and determining horizon thickness and soil depth. In addition, studies were conducted to see root impediments, structure, drainage, color, consistency, declivity and other attributes that support the classifications.

Samples were taken from all the horizons for chemical and physical analysis, and were determined by UFT's Soil Laboratory, being characterized according to the methodology proposed by Embrapa (1997). In the chemical analysis were determined $\mathrm{pH}, \mathrm{Ca}^{2+}, \mathrm{Mg}^{2+}$ and $\mathrm{K}^{+}$exchangeable, available $\mathrm{P}$, organic matter (OM\%), total cation exchange capacity (CEC T), effective cation exchange capacity (CEC $t$ ), base saturation $(\mathrm{V} \%)$, aluminum saturation $(\mathrm{m} \%)$, sum of base $(\mathrm{SB})$, exchangeable acidity $\left(\mathrm{Al}^{3+}\right), \mathrm{H}+\mathrm{Al}$ (potential acidity), and texture analysis (\% of sand, silt and clay).

There are many classification systems in the world, most of being national and international. The present study were made using the guide of soil classification the Brazilian System of Soil Classification (EMBRAPA, 2013). Thus, was conducted a descriptive study of all the horizons. In addition, this work attempt was made to classify soil up to the fourth category level, using the data obtained by the study of soil analyzes. Furthermore, for soil classification and agricultural usage were collected data about soil management made in recent years in the area, such as erosion presence, slope, stoniness, soil cover and mechanization practices.

The methodology adopted was following Ramalho Filho e Beek (1995) evaluating fertility, water, oxygen deficiency, erosion susceptibility, mechanization restriction and the possibilities to improve the conditions. The classification of Ramalho \& Beek (1995) is based on six capability groups: 1, 2 and 3 - ability to crop cultivation; 4 - cultivated pasture; 5 - forestry and/or natural pasture; 6 - preservation of flora and fauna (groups 1 to 5 divided into classes: good, regular and restricted; and class 6: without agriculture potential).

\section{RESULTS AND DISCUSSION}

After the diagnostic produced by the study, four soil classes were obtained: Plintossolo Argilúvico Distrófico petroplíntico (FTd), Cambissolo Háplico Tb Eutrófico (CXbe), Latossolo Vermelho-Amarelo Distrófico típico (LVAd) and Gleissolo Melânico Ta Eutrófico (GMve) according to the SiBCS (EMBRAPA, 2013).

Table 1. Chemical and physical properties of the four profiles studied.

\begin{tabular}{|c|c|c|c|c|c|c|c|c|c|}
\hline \multicolumn{10}{|c|}{ FTd- Plintossolo Argilúvico Distrófico petroplíntico } \\
\hline \multirow{2}{*}{ Horizon } & $\mathrm{Ca}$ & $\mathrm{Mg}$ & $\mathrm{Al}^{3+}$ & $\mathrm{H}+\mathrm{Al}$ & K & CEC(T) & SB & $\mathrm{CEC}(\mathrm{t})$ & $P$ \\
\hline & \multicolumn{8}{|c|}{ 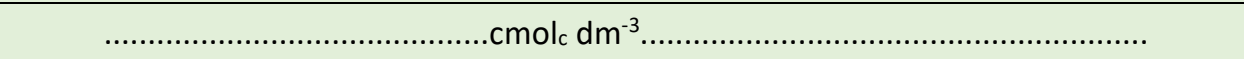 } & $\mathrm{mg} \mathrm{dm} \mathrm{m}^{-3}$ \\
\hline$A(0-30)$ & 0.82 & 0.28 & 0.00 & 1.21 & 0.05 & 3.36 & 1.15 & 1.15 & 3.98 \\
\hline$E(30-45)$ & 0.70 & 0.54 & 0.00 & 1.75 & 0.01 & 3.00 & 1.25 & 1.25 & 4.35 \\
\hline Btf $(45+)$ & 0.49 & 0.12 & 0.00 & 0.86 & 0.01 & 1.48 & 0.62 & 0.62 & 3.60 \\
\hline \multirow{2}{*}{ Horizon } & \multicolumn{2}{|c|}{................. } & O.C. & O. M. & $\mathrm{pH}$ & & \multicolumn{3}{|c|}{...........Texture $\left(\mathrm{g} \mathrm{kg}^{-1}\right) \ldots \ldots \ldots$} \\
\hline & $\mathrm{V}$ & $\mathrm{m}$ & \multicolumn{2}{|c|}{$\ldots \ldots . . \mathrm{g} \mathrm{kg}^{-1} \ldots \ldots$} & $\mathrm{H}_{2} \mathrm{O}$ & & Sand & Silt & Clay \\
\hline$A(0-30)$ & 34.28 & 0.00 & 24.96 & 14.48 & 6.09 & & 547.35 & 97.73 & 354.92 \\
\hline$E(30-45)$ & 41.74 & 0.00 & 27.58 & 16.00 & 6.20 & & 497.35 & 47.73 & 454.92 \\
\hline Btf (45+) & 41.97 & 0.00 & 16.31 & 9.46 & 6.15 & & 314.03 & 97.73 & 588.24 \\
\hline
\end{tabular}

To be continued 
Table $1 . .$. Continued

\begin{tabular}{|c|c|c|c|c|c|c|c|c|c|}
\hline \multicolumn{10}{|c|}{ CXbe - Cambissolo Háplico Tb Eutrófico } \\
\hline \multirow{2}{*}{ Horizon } & $\mathrm{Ca}$ & $\mathrm{Mg}$ & Al & $\mathrm{H}+\mathrm{Al}$ & $\mathrm{K}$ & $\mathrm{CEC}(\mathrm{T})$ & SB & $\mathrm{CEC}(\mathrm{t})$ & $\mathrm{P}$ \\
\hline & \multicolumn{8}{|c|}{ 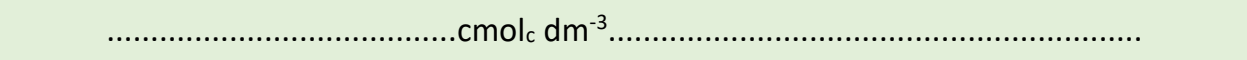 } & $\mathrm{mg} \mathrm{dm}{ }^{-3}$ \\
\hline$A(0-38)$ & 2.34 & 1.58 & 0.00 & 3.65 & 0.03 & 7.60 & 3.95 & 3.95 & 5.48 \\
\hline $\mathrm{Bi}(38-74)$ & 1.10 & 1.47 & 0.00 & 2.38 & 0.02 & 4.96 & 2.59 & 2.59 & 4.35 \\
\hline$C(74+)$ & - & - & - & - & - & - & - & - & - \\
\hline \multirow{2}{*}{ Horizon } & \multicolumn{2}{|c|}{................ } & O. C. & O. M. & $\mathrm{pH}$ & & \multicolumn{3}{|c|}{..........Texture $\left(\mathrm{g} \mathrm{kg}^{-1}\right) \ldots \ldots .}$. \\
\hline & V & $\mathrm{m}$ & \multicolumn{2}{|c|}{$\ldots \ldots \ldots \mathrm{g} \mathrm{kg}^{-1} \ldots \ldots$} & $\mathrm{H}_{2} \mathrm{O}$ & & Sand & Silt & Clay \\
\hline$A(0-38)$ & 52.02 & 0.00 & 64.63 & 37.49 & 6.20 & & 647.35 & 114.4 & 238.26 \\
\hline $\mathrm{Bi}(38-74)$ & 52.11 & 0.00 & 25.96 & 15.06 & 6.12 & & 630.68 & 47.73 & 321.59 \\
\hline$C(74+)$ & - & - & - & - & - & - & - & - & - \\
\hline \multicolumn{10}{|c|}{ LVAd - Latossolo Vermelho-Amarelo Distrófico típico } \\
\hline \multirow{2}{*}{ Horizon } & $\mathrm{Ca}$ & $\mathrm{Mg}$ & Al & $\mathrm{H}+\mathrm{Al}$ & K & $\mathrm{CEC}(\mathrm{T})$ & SB & $\mathrm{CEC}(\mathrm{t})$ & $\mathrm{P}$ \\
\hline & \multicolumn{8}{|c|}{. $\mathrm{cmol}_{\mathrm{c}} \mathrm{dm}^{-3}$} & $\mathrm{mg} \mathrm{dm} \mathrm{m}^{-3}$ \\
\hline$A(0-10)$ & 0.95 & 1.19 & 0.00 & 2.19 & 0.18 & 4.51 & 2.32 & 2.32 & 4.73 \\
\hline Bw $(10-120+)$ & 0.35 & 0.19 & 0.00 & 1.86 & 0.01 & 2.42 & 0.55 & 0.55 & 3.60 \\
\hline \multirow{2}{*}{ Horizon } & \multicolumn{2}{|c|}{................ } & O. C. & O. M. & $\mathrm{pH}$ & & \multicolumn{3}{|c|}{.........Texture $\left(\mathrm{g} \mathrm{kg}^{-1}\right) \ldots \ldots \ldots$} \\
\hline & V & $\mathrm{m}$ & \multicolumn{2}{|c|}{$\ldots \ldots . . \mathrm{g} \mathrm{kg}^{-1} \ldots \ldots$} & $\mathrm{H}_{2} \mathrm{O}$ & & Sand & Silt & Clay \\
\hline$A(0-10)$ & 51.34 & 0.00 & 27.19 & 15.77 & 6.00 & & 564.02 & 47.73 & 388.25 \\
\hline Bw (10-20+) & 22.88 & 0.00 & 9.86 & 5.72 & 6.10 & & 464.02 & 81.06 & 454.92 \\
\hline \multicolumn{10}{|c|}{ GMve - Gleissolo Melânico Ta Eutrófico } \\
\hline \multirow{2}{*}{ Horizon } & $\mathrm{Ca}$ & $\mathrm{Mg}$ & Al & $\mathrm{H}+\mathrm{Al}$ & K & $\mathrm{CEC}(\mathrm{T})$ & SB & $\mathrm{CEC}(\mathrm{t})$ & $P$ \\
\hline & \multicolumn{8}{|c|}{. } & $\mathrm{mg} \mathrm{dm} \mathrm{m}^{-3}$ \\
\hline$A(0-40)$ & 4.17 & 1.81 & 0.00 & 2.71 & 0.02 & 8.71 & 6.00 & 6.00 & 8.86 \\
\hline $\mathrm{Cg}(40-75)$ & 1.15 & 1.40 & 0.00 & 1.54 & 0.01 & 5.10 & 2.56 & 2.56 & 5.10 \\
\hline \multirow{2}{*}{ Horizon } & \multicolumn{2}{|c|}{................ } & O. C. & O. M. & $\mathrm{pH}$ & & \multicolumn{3}{|c|}{...........Texture $\left(\mathrm{g} \mathrm{kg}^{-1}\right) \ldots \ldots \ldots$} \\
\hline & V & $\mathrm{m}$ & .......... & 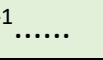 & $\mathrm{H}_{2} \mathrm{O}$ & & Sandy & Silt & Clay \\
\hline$A(0-40)$ & 68.92 & 0.00 & 53.15 & 30.83 & 5.93 & & 647.35 & 147.73 & 204.9 \\
\hline $\mathrm{Cg}(40-75)$ & 50.19 & 0.00 & 20.53 & 11.91 & 6.18 & & 380.69 & 97.73 & 521.58 \\
\hline
\end{tabular}

Ca: Calcium; Mg: Magnesium; Al: Aluminum; H + Al: Hydrogen + Aluminum (potential acidity); K: Potassium; CEC (T): Cation Exchange Capacity Total; SB: Basic Sum; CEC ( $t$ ): Effective Cation Exchange Capacity; P: Phosphorus; V(\%) saturation by bases; $\mathrm{m}(\%)$ saturation by aluminum; O.C.: Organic Carbon; O.M.: Organic Matter; pH: potential hydrogen (Active Acidity).

The profiles characterization (Table 1 ) indicated a significant fertility difference between studied soils, wherefore influence in agricultural usage determination with its morphological characteristics. Table 2 and Figure 1 show morphological characteristics and profiles, respectively. 
Table 2. Morphological properties of studied profiles.

\begin{tabular}{|c|c|c|c|c|c|c|c|}
\hline \multirow{2}{*}{ Horizon } & \multirow{2}{*}{$\begin{array}{l}\text { Depth } \\
(\mathrm{cm})\end{array}$} & \multirow{2}{*}{$\begin{array}{l}\text { Color } \\
\text { (Dry) }\end{array}$} & \multirow{2}{*}{ Texture } & \multirow{2}{*}{ Structure } & \multicolumn{3}{|c|}{ Consistency } \\
\hline & & & & & Dry & Moist & Wet. \\
\hline \multicolumn{8}{|c|}{ Plintossolo Argilúvico Distrófico petroplíntico (FTd) } \\
\hline A & $0-30$ & $10 Y R 5 / 6$ & sandy clay loam & sab. & $\mathrm{H}$ & $\mathrm{PL}$ & ST \\
\hline $\mathrm{E}$ & $30-45$ & 10YR6/8 & sandyc Clay & sab & $\mathrm{SH}$ & PL & ST \\
\hline Btf & $45+$ & 7,5 YR $6 / 8$ & clay & sab & $\mathrm{EH}$ & PL & ST \\
\hline \multicolumn{8}{|c|}{ Cambissolo Háplico Tb Eutrófico (CXbe) } \\
\hline A & $0-38$ & $10 Y R 4 / 4$ & Sandy clay loam & gr & $\mathrm{H}$ & ST & VS \\
\hline $\mathrm{Bi}$ & $38-74$ & 10YR 6/8 & Sandy clay loam & sab & $\mathrm{H}$ & ST & VS \\
\hline C & $74+$ & - & - & - & - & - & - \\
\hline \multicolumn{8}{|c|}{ Latossolo Vermelho-Amarelo Distrófico típico (LVAd) } \\
\hline A & $0-10$ & 5YR $6 / 8$ & sandy clay loam & gr & $\mathrm{Fr}$ & $\mathrm{PL}$ & ST \\
\hline Bw & $10-120+$ & $5 Y R 6 / 8$ & clay & $\mathrm{gr}$ & $\mathrm{Fr}$ & $\mathrm{PL}$ & ST \\
\hline \multicolumn{8}{|c|}{ Gleissolo Melânico Ta Eutrófico (GMve) } \\
\hline A & $0-40$ & $5 Y R 3 / 2$ & sandy clay loam & gr & $\mathrm{H}$ & $\mathrm{PL}$ & ST \\
\hline $\mathrm{Cg}$ & $40-75+$ & $5 Y 8 / 2$ & clay & sab & $\mathrm{H}$ & VPL & VS \\
\hline
\end{tabular}

Structure: granular (gr), subangular blocky (sab); Consistency: slightly hard (SH), hard (H), extremely hard (EH); friable (Fr); plastic (PL); very plastic (VPL); sticky (ST), very sticky (VS).

The Plintossolo Argilúvico Distrófico petroplíntico (FTd) have plain relief, declivity of $1.15 \%$, moderate drain and erosion in furrows. Current use with grass Brachiaria brizantha cv. Marandu. Horizon Btf presented with abundant presence of speckles petroplinthite reddish color brown (5yr 5/8). Abundant roots up to $60 \mathrm{~cm}$ deep, with abundant presence of petroplinthite (>15\%) from $42 \mathrm{~cm}$ ).

The Cambissolo Háplico Tb Eutrófico (CXbe) showed plain relief; moderate drainage imperfectly drained; declivity of $2.81 \%$; no apparent erosion, current use with grass Brachiaria brizantha cv. Marandu, abundant root to $70 \mathrm{~cm}$ depth; presence of superficial stoniness and the horizon $A$.

The Latossolo Vermelho-Amarelo Distrófico típico (LVAd) presented the plan relief undulated; declivity of 3.03\%; well drained; no apparent erosion; Current use with grass Brachiaria brizantha cv. Marandu. It presented root to a depth of $1.20 \mathrm{~m}$.

The Gleissolo Melânico Ta Eutrófico (GMve) indicated plain relief; declivity of 2.78\%; poorly drained; no erosion; Current use with grass Brachiaria brizantha cv. Marandu. Presented root up to $45 \mathrm{~cm}$; poorly drained.
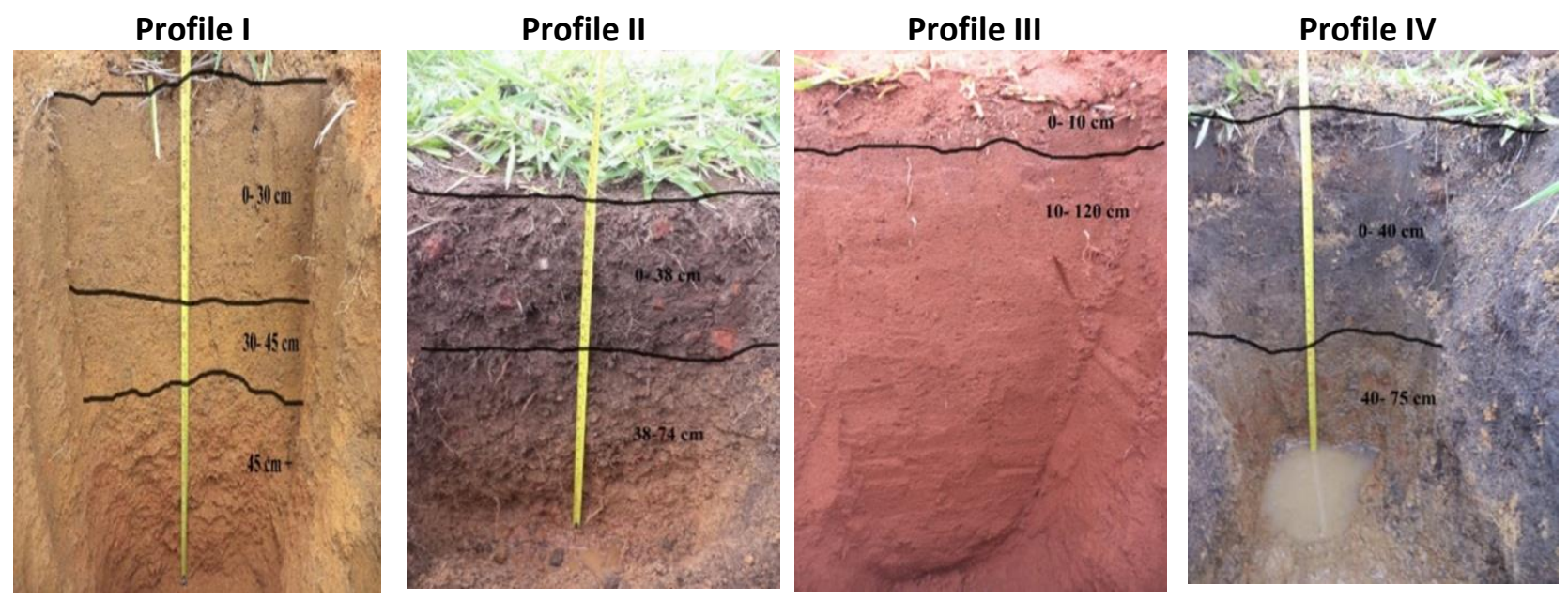

Figure 1. Plintossolo Argilúvico Distrófico petroplíntico (FTd) (Profile I), Cambissolo Háplico Tb Eutrófico (CXbe) (Profile II), Latossolo Vermelho-Amarelo Distrófico típico (LVAd) (Profile II) and Gleissolo Melânico Ta Eutrófico (GMve) (Profile IV). 
All soils were being used for livestock in a rotational system, being cultivated with 46.42 hectares covered by grass Brachiaria brizantha cv. Marandu. Nearby, there were 6.3 hectares used as forest reserve and permanent preservation area (APP), and a dam with 0.63 hectares of extension (Figure 1). At the evaluation time, there were few ground cover because heads of cattle were grazing in the area. However, the pasture still indicated good level of preservation, without degradation exposed. In addition, annually cattle manure and slaughterhouse residue are applicate in the area.

Second Ramalho Filho \& Beek (1995), determination of soil suitability is defined setting up its appropriate use according to capacities and limitations (Table 3). According to the management performed in Nelore Brilhant farm, the land conservation and management level classify this farm as B. In other words, it appointed technological level ranked as medium, characterized by modest capital investment and research results to management.

I

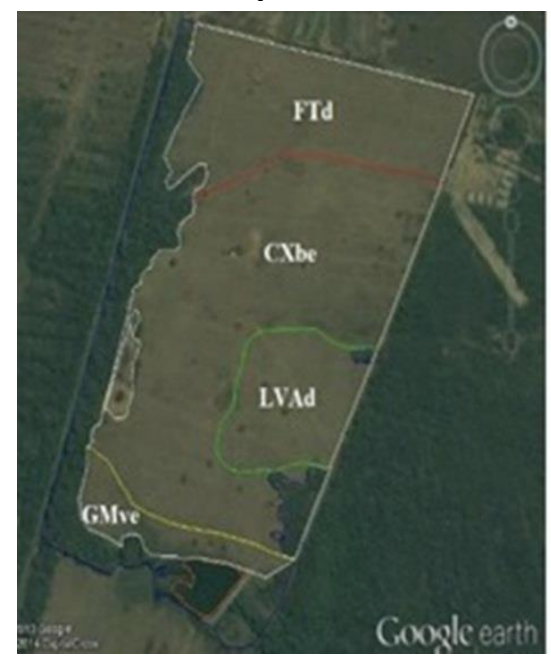

II

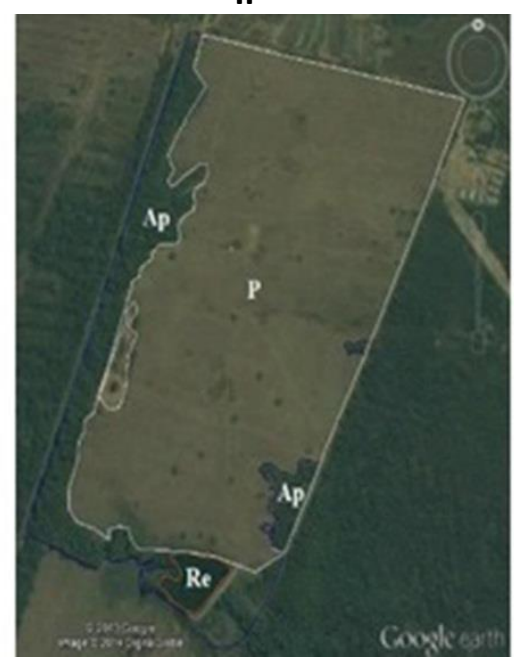

III

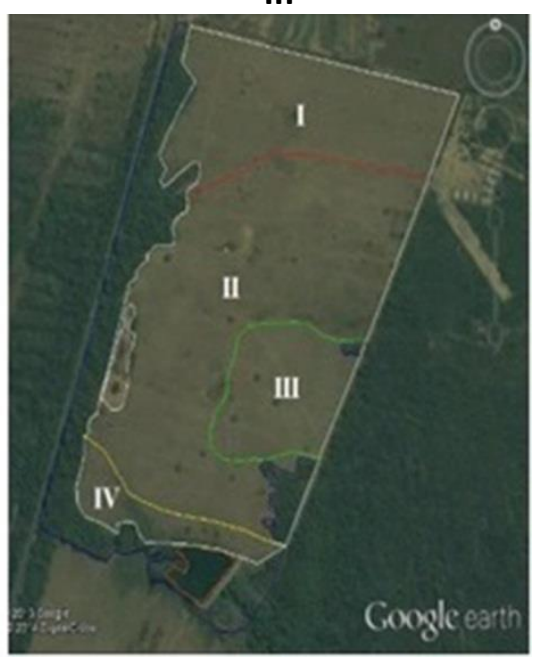

Figura 2. Soil distribution (I), current use (II) and agricultural potential (III) of area soils studied. Source: Google Earth. (I) FTd - Plintossolo Argilúvico Distrófico petroplíntico; CXbe - Cambissolo Háplico Tb Eutrófico; LVAd - Latossolo VermelhoAmarelo Distrófico típico; GMve - Gleissolo Melânico Ta Eutrófico. (II) P- Pasture with grass Brachiaria brizantha cv. Marandu; Ap- preservation area; Re- Dam. (III) I- Short-cycle crops or long; II- Pasture planted, native forest; III- Crops short cycle; IV- Short-cycle crops or long.

Table 3. Soil agricultural suitability classification and limitation levels.

\begin{tabular}{|c|c|c|c|c|c|c|c|c|}
\hline \multirow{2}{*}{ Soil ${ }^{(1)}$} & \multirow{2}{*}{ Group } & \multirow{2}{*}{ Subgroup (2) } & \multicolumn{6}{|c|}{ Soil limitation leves ${ }^{(3)}$} \\
\hline & & & $f$ & w & 0 & $\mathrm{e}$ & $\mathrm{m}$ & $\mathrm{Vm}$ \\
\hline FTd & 1 & $1(a) b C$ & $M$ & $\mathrm{M}$ & $\mathrm{L}$ & $\mathrm{N}$ & $M$ & 2 \\
\hline cXbe & 4 & $4 \mathrm{P}$ & $\mathrm{L}$ & $\mathrm{M}$ & $\mathrm{L}$ & $\mathrm{L}$ & L & 2 \\
\hline LVAd & 1 & $1 \mathrm{aBC}$ & $M$ & $\mathrm{M}$ & $N$ & $\mathrm{~L}$ & $\mathrm{~N}$ & 2 \\
\hline GMve & 3 & $3(b c)$ & $M$ & $\mathrm{~N}$ & $\mathrm{H}$ & $\mathrm{N}$ & $M$ & 2 \\
\hline
\end{tabular}

${ }^{(1)}$ FTd - Plintossolo Argilúvico Distrófico petroplíntico; CXbe - Cambissolo Háplico Tb Eutrófico; LVAd - Latossolo VermelhoAmarelo Distrófico típico; GMve - Gleissolo Melânico Ta Eutrófico;

${ }^{(2)} 1(\mathrm{a}) \mathrm{bC}$ - Short cycle crops or long, restricted potential level A, regular on level B and good level C; 4P-pasture planted with good potential; $1 \mathrm{~B} B \mathrm{C}$ - short cycle crops, regular potential on level A and good on level B and C; 3 (bc)- Long or short cycle crops, potential restricted on level B and C.

(3)f - fertility deficiency; w - water deficiency; o- oxygen deficiency; e- erosion susceptibility; m- mechanization impediment; vm - improving viability; $\mathbf{N}$ - null; L- light; $\mathbf{M}$-moderate; $\mathbf{H}$ - hard. 
The Plintossolo Argilúvico Distrófico petroplíntico (FTd) arranged in agricultural capability group 1, regular potential for crops with short or long cycle according to use management level, which has some limitations for the development of crops. Thus, it was classified in subgroup 1 (a)bC, based on soil characteristics, classes and capacity groups (RAMALHO FILHO; BEEK, 1995).

Regarding limitations present in the soil, the methodology proposed by Ramalho Filho \& Beek (1995) was used to determine its characteristic level. For the soil fertility limitation ( $f$ ) it was classified as moderate $(M)$, limited reserves of some nutrients. The water deficiency $(\mathrm{w})$ was moderate $(\mathrm{M})$, with a considerable deficiency of available water during 3 to 6 months in the year. In relation to oxygen deficiency (o), it was classified as light (L), having small aeration for sensitive plants in the wet season, whereas it is moderately drained. The soil showed null (N) erosion susceptibility (e) flat relief or almost flat, with declivity less than $3 \%$. The area presented moderate (M) mechanization impediments $(\mathrm{m})$. The main impediment was related to drainage restriction in the rainy season.

Delarmelinda (2011) evaluating different soils in Acre, ranked Plintossolos Háplicos, Eutróficos and Argilúvicos in subgroups 2(a)bc, 2(a)bc and 3 (abc) respectively. Santana et al. (2010) studying soils of Santa Tereza - Tocantins, classified Plintossolo in 4P subgroup, however the Plintossolo predominant were pétrico, justifying the classification.

The Cambissolo Háplico Tb Eutrófico (CXbe) was classifield in the group 4 for agricultural capacity, being indicated for planted pastures or natural pasture, silviculture, preservation of flora and fauna, thus being an area with less value for agriculture. The agricultural capacity according to the potential group was classified as good. It is a soil without significant limitations to pastures, observing management conditions to improve the system. There is minimum restrictions that does not reduce significantly productivity and benefits, without increase inputs above an acceptable level for the indicated use. Therefore, the soil was ranked in the subgroup 4P second Ramalho Filho \& Beek (1995).

The soil limitation, based on methodologies Ramalho Filho \& Beek (1995) fertility deficieny level (f) was classified as light (L), presenting good reserves of nutrients and no toxic elements. Thus, this soil has the potential for good yields with little requirement for maintenance of nutritional status. The water deficiency $(w)$ was classified as moderate (M), with a considerable water deficiency available over a period of 3 to 6 months or slightly less. This soil has low water retention capacity with a shallow profile that can be soaked in case of high precipitation. Oxygen limitation classification (o) was light (L) deficiency and may be a problem for sensitive plants in the rainy season, being a soil moderately drained. It has light (L) erosion susceptibility (e) presenting undulated relief (declivity between 3 and $8 \%$ ) and good physical properties in the profile. This soil contains light $(\mathrm{L})$ mechanization restriction $(\mathrm{m})$ being a soft wavy topography, with few impediments such as stoniness or rockiness. Therefore, it is possible to use most agricultural machinery.

Agreeing with the classification given to this soil, Corseuil et al. (2009) evaluating agricultural potential with the use of GIS and remote sensing have classified Cambissolos in $4 p$ sub-group. Marques et al. (2012) evaluating the agricultural suitability of different soils in Paracatu river watershed, classified the Cambissolo Háplico Tb Eutrófico present in their study ranging between subgroups $2(a b c), 3(a)$ and $4 p$ according to the methodology of Beek et al. (1964), Ramalho Filho \& Beek (1995) and Marques (2004), respectively.

Menezes et al. (2009) evaluating soils in sub watershed of Minas Gerais have classified Cambissolo Háplico in subgroup $4 p$ - regular potential for planted pasture and 
5S - good potential for silviculture. Araújo et al. (2013) evaluating the micro-region's agricultural potential in Mossoro-RN ranked Cambissolos in subgroup 3(abc). Pedron et al. (2006) classified the Cambissolo Háplico Ta eutrófico típico in the subgroup 3(a) in transition to 4p. Santana et al. (2010) carrying out studies in Santa Tereza-TO, classified Cambissolo in the subgroup 4(p). Smith et al. (2011) in a survey about agriculture potential use and environmental legislation in the watershed of Pequeno river, classified Cambissolo in the subgroup $2(\mathrm{ab}) \mathrm{c}, 3(\mathrm{abc}), 4 \mathrm{P}$ and 6 , according to the terrain slope.

The Latossolo Vermelho-Amarelo Distrófico típico (LVAd) was ranked in the group 1 , being indicated for crops that require high management. The soil showed good agricultural potential class without significant limitations for the sustained production. There are minimum restrictions that does not reduce significantly productivity or benefits, and does not increase inputs above acceptable level for this group. Based on the group and soil capacity class, it was classified in subgroup $1 \mathrm{aBC}$, according to Ramalho Filho \& Beek (1995).

Following the methodology of Ramalho Filho \& Beek (1995) the found soil limitation was moderate (M) for fertility deficiency (f) with limited reserve for some nutrients. This soil has good potential for high yield in the early years, however can have a rapid decline after years. It has moderate $(M)$ water deficiency $(w)$, over a period from 3 to 6 months. Mechanization impediments $(\mathrm{m})$ are null $(\mathrm{N})$, because it has a flat or nearly flat topography, with no material impediment to machine use or agricultural implement.

Delarmelinda et al (2014) evaluating a Latossolo Amarelo in the State of Acre determined its agricultural use as subgroup 3(b), 2(a)BC, 2(a)bc, 1(a)bC, 1(a)Bc and $1 b C$. Marques et al. (2012) evaluating different Latossolos in the watershed of Paracatu river rated it in the subgroup 2(a)c and 3a(c) as Beek et al. (1964), and 2(b)c according to Ramalho Filho \& Beek (1995), 1(bc) and 1(b)c second Marques (2004). Menezes et al. (2009) in their study evaluating lands of watershed in the State of Minas Gerais, rated Latossolo Vermelho-Amarelo in the subgroup 3(bc) and 4P. Moura et al. (2007) in Machado - Minas Gerais, classified studied Latossolos in the subgroup 2(ab)c.

The Gleissolo Melânico Ta Eutrófico (GMve) was classified in the group 3, with restrictions for intolerant crops to poor soil drainage, nevertheless there are no limitations for planted/natural pasture, preservation of flora and fauna and and/or silviculture. So being classified in the subgroup 3(bc) second Ramalho Filho \& Beek (1995).

The fertility limitation (f) was moderate (M) with limited reserves for some nutrients as phosphorus $(\mathrm{P})$ and potassium $(\mathrm{K})$. As for the water deficiency $(\mathrm{W})$ was considered null $(\mathrm{N})$, with no deficiency because the water table this area was high with small variation, and besides a part remains that waterlogged along the year. Consequently, the oxygen deficiency $(\mathrm{o})$, is hard $(\mathrm{H})$, because during the rainy season the area remains flooded, limiting crop deployment, however in dry season only the lower area is limited by oxygen deficiency. This soil shows null (N) erosion susceptibility (e). The declive was $2.78 \%$, considering flat relief, and erosion can be controlled by simple conservation practices. The mechanization impediment was moderate $(\mathrm{M})$, allowing the use of tractors and implements, however during the rainy season there are impediments in related to the presence of water.

In agreement with the results presented in this study, Santos \& Klamt (2004) aiming classified Gleissolo Melânico Eutróficos and Gleissolo Melânico Distrófico in subgroups 3 (bc) and 4P respectively. On the other hand, Moura et al. (2007) in Salinas - Minas Gerais similarly to Sousa et al. (2012) in Buenos Aires - Pernambuco, classified Gleissolos in subgroup 4P, considering areas for regular use of planted pastures. Marques et al. (2012) also studying a Gleissolo Melânico ranked it in subgroup 6 (without 
agriculture potential) according to the methodologies Beek et al. (1964), Ramalho Filho \& Beek (1995) and Marques (2004). In contrast, Barbosa Neto (2011) rated a Gleissolo Háplico in 4P subgroup.

In short, land use and agricultural production without planning have compromised the natural systems sustainability, leading to degradation, productivity decrease, causing impact environmental, economic and social at local and regional levels. In this context, is inserted agricultural capability of the soil, which support agriculture production planning for different types of use, looking to fulfill a ratio of cost/benefit under the points of view economic and environmental (MENEZES et al., 2009; RAMALHO FILHO; BEEK, 1995).

Table 4 presents a summary of the agricultural capability of soils and area (ha) corresponding to each soil.

Table 4. Distribution of agricultural capability in the studied area.

\begin{tabular}{ccccc}
\hline Soil $^{(1)}$ & Subgroup $^{(2)}$ & Agricultural potential & Area (ha) & $\%$ \\
\hline FTd & $1(\mathrm{a}) \mathrm{bC}$ & Short-cycle crops or long & 15.317 & 28.71 \\
CXbe & $4 \mathrm{P}$ & Pastures planted & 23.343 & 43.76 \\
LVAd & $1 \mathrm{aBC}$ & Crops short cycle & 05.056 & 09.48 \\
GMve & $3(\mathrm{bc})$ & Short-cycle crop or long & 02.706 & 05.08 \\
- & - & Reserve and conservation area & 06.297 & 11.80 \\
- & - & Dam & 00.628 & 01.17 \\
- & - & Total & 53.347 & 100.00 \\
\hline
\end{tabular}

(1) FTd - Plintossolo Argilúvico Distrófico petroplíntico; CXbe - Cambissolo Háplico Tb Eutrófico; LVAd - Latossolo VermelhoAmarelo Distrófico típico; GMve - Gleissolo Melânico Ta Eutrófico;

(2) 1 (a)bC - restricted potential for short or long cycle crops in level A, regular on level B and good in level C; 4P- Good potential for planted pastures; $1 \mathrm{aBC}$ - regular potential for short cycle crops on level A, and good on level B and C; $3(\mathrm{bc})$ - potential restricted to short cycle crops or long on levels B and C.

\section{CONCLUSIONS}

The studied field has underutilized area being used for pasture cultivation, at the same time it could be used for growing annual plants.

For the current use, there are no restrictions in the areas and it can continue be used for pasture.

Conservation practices need to be adopt in the studied area due to the presence of points of laminar erosion.

\section{AUTHORS CONTRIBUITION}

Study of the trenches; Determination of soil morphological characteristics; Soil classification; Laboratory analysis; Elaboration of the manuscript, correction, editing and finalization of the manuscript: JSSC, DBS, RCL, JVCG, GCMF e SOL.

\section{COMPETING INTERESTS}

The authors declare there are no competing interests.

\section{FUNDING}

The authors received no funding this work. 


\section{REFERENCES}

ARAÚJO, J.M.S.; OLIVEIRA, H.A.; BEZERRA, H.N.; SILVA, P.C.M. Determinação da aptidão agrícola da microrregião de Mossoró-RN. Engenharia na agricultura, v.21 n.2, p.148-158, 2013.

BARBOSA NETO, M.V. Zoneamento da aptidão agrícola e uso dos solos da área do médio curso do rio Natuba - PE. 134 f. Dissertação (Mestrado em Geografia). Universidade Federal de Pernambuco - UFPE, Recife, 2011.

BEEK, K.J., BENNEMA, J., CAMARGO, M.N. Soil survey interpretation in Brazil. A system of land capability classification for reconnaissance surveys. Wageningen: DPES/FAO/STIBOKA, 1964, 36p.

CORSEUIL, C.W.; CAMPOS, S.; RIBEIRO, F.L.; PISSARRA, T.C.T.; RODRIGUES, F.M. Geoprocessamento e sensoriamento remoto aplicado na determinação da aptidão agrícola de uma microbacia. Irriga, v.14, n.1, p. 12-22, 2009.

DELARMELINDA, E.A. Aplicação de sistemas de avaliação da aptidão agrícola em solos do Estado do Acre. 141 f. Dissertação (Mestrado em Agronomia). Universidade Federal do Acre, Rio Branco, 2011.

DELARMELINDA, E.A.; WADT, P.G.S.; ANJOS, L.H.C.; MASUTTI, C.S.M.; SILVA, E.F.; SILVA, M.M.; COELHO, R.M.; SILVA, L.M.; SHIMIZU, S.H.; COUTO, W.H. Aplicação de sistemas de avaliação da aptidão agrícola das terras em solos do Estado do Acre, Amazônia. Biota Amazônia, v. 4, n. 2, p. 87-95, 2014.

EMBRAPA - Empresa Brasileira de Pesquisa Agropecuária. Análises Químicas. In: EMBRAPA - Empresa Brasileira de Pesquisa Agropecuária. Manual de métodos de análises de solo. Centro Nacional de Pesquisa de Solos. 2. ed. Rio de Janeiro: Embrapa Solos, p. 81 - 181, 1997.

EMBRAPA - Empresa Brasileira de Pesquisa Agropecuária. Sistema brasileiro de classificação de solos. Centro Nacional de Pesquisa de Solos, 3. ed. Brasília: Embrapa Solos, 2013. 353 p.

GUIMARÃES, E.S.; SANTOS, C.L.; AZEVEDO, L.J.; MELLO, A.H. Caracterização morfológica dos solos de quintal agroflorestal, floresta secundária e cultivo de maracujá (Passiflora edulis) no assentamento alegria, sudeste do Pará. Agroecossistemas. v. 5, n. 1, p. 45-49, 2013.

KÖPPEN, W. Climatologia: con un estudio de los climas de la tierra. Fondo de Cultura Econômica. México, 1948, p. 479.

MARQUES, A.F.S.M. Proposta de modificações ao sistema brasileiro de aptidão agrícola das terras. Belo Horizon: FAO, 2004.

MARQUES, A.F.S.M.; MARTINS JUNIOR, P.P.; VASCONCELOS, V.V.; NOVAES, L.A. D’A. Proposição Metodológica para a Cartografia de Solos e Aptidão Agrícola: Estudo de Caso para a Bacia do Rio Paracatu. Revista Brasileira de Geografia Física, v. 01 p.01-17, 2012.

MENEZES, M.D.; CURI, N.; MARQUES, J.J.; MELLO, C.R.; ARAÚJO, A.R. Levantamento pedológico e sistema de informações geográficas na avaliação do uso das terras em sub-bacia hidrográfica de Minas Gerais. Ciência e Agrotecnologia, v. 33, n. 6, p. 1544-1553, 2009.

MOURA, L.C.; MARQUES, A.F.S.M.; HADAD, R.M.; ANDRADE, H.; ALVES, H.M.R. A aptidão agrícola das terras do município de Machado/MG e a cafeicultura. Caderno de Geografia, v. 17, n. 28, p. 141-162, 2007.

OLIVEIRA, J.B. Pedologia Aplicada. 3a Ed. Piracicaba: FEALQ. 2008. p.292.

PEDRON, F.A. POELKING, E.L.; DALMOLIN, R.S.D.; AZEVEDO, A.; KLANT, E. A aptidão de uso da terra como base para o planejamento da utilização dos recursos naturais no município de São João do Polêsine - RS. Ciência Rural, v. 36, n.1, p. 105-112, 2006.

RAMALHO FILHO, A., BEEK, K.J. Sistema de avaliação da aptidão agrícola das terras. (3ำed. Revisada). 1995. Rio de Janeiro: SUPLAN-EMBRAPA/SNLCS, p.65.

ROSSITER, D.G.A. Theoretical framework for land evaluation. Geoderma, v.72, p.165-190, 1996. 
SANTANA, H.M.P.; LACERDA, M.P.C.; BARROS. M.A.; BARBOSA, I.O. Unidades pedoambientais da região de Santa Tereza, estado do Tocantins. Pesquisa Agropecuária Tropical, v. 40, n. 1, p. 8-19, 2010.

SANTOS, F.J. \& KLAMT, E. Gestão agroecológica de microbacias hidrográficas através de técnicas de geoprocessamento e sensoriamento remoto - caso Fazenda Pantanoso. Ciência Rural, v.34, n.6, p.17851792, 2004.

SANTOS, R.D; SANTOS, H.G.; KER, J.C.; ANJOS, L.H.C.; SHIMIZU, S.H. Manual de Descrição e Coleta de Solo no Campo. 6ạ edição revisada e ampliada. Viçosa, Sociedade Brasileira de Ciência do Solo, 2013. 100p.

SCHNEIDER, P.; GIASSON, E.; KLAMT, E.; SCHNEIDER, P. Classificação da aptidão agrícola das terras: um sistema alternativo. Guaíba: Agrolivros, 2007, p,72.

SOARES, M.R.G.J.; SOUZA, J.L.M.; JERSZURKI, D. Potencial de uso agrícola e legislação ambiental voltados ao planejamento na bacia do Rio Pequeno-PR. RAEGA - O Espaço Geográfico em Análise, v.21, p. 186-203, 2011.

SOUSA, A.R.; SILVA, A.B.; GALLINDO, F.A.T.; SÁ, V.A.L.; NUNES FILHO, J.; ACCIOLY, L.J.O. Aptidão agrícola das terras do município de Buenos Aires, Pernambuco. Pesquisa Agropecuária Pernambucana, v. 17, n. único, p. 90-93, 2012. 